\title{
Akran Değerlendirmenin Öğretmen Adaylarının Mesleki Bilgi ve Becerilerine Etkisinin İncelenmesi
}

\author{
Investigating the Effect of Peer Assessment on Preservice Teachers' to Professional \\ Knowledge and Skills
}

\section{Vural TÜNKLER ${ }^{*}$}

\section{Öz}

$\mathrm{Bu}$ araştırmanın amacı, akran değerlendirmenin sosyal bilgiler öğretmen adaylarının mesleki bilgi ve becerileri üzerindeki etkisinin incelenmesidir. Araştırma kapsamında ayrıca öğretmen adaylarının akran değerlendirmeye ilişkin görüşleri de araştırılmıştır. Araştırma karma yöntem yaklaşımlarından yakınsayan paralel desen kullanılarak tasarlanmıştır. Araştırmanın çalışma grubunu bir devlet üniversitesinin Sosyal Bilgiler Eğitimi Anabilim Dalında öğrenim gören 35 öğretmen adayı oluşturmaktadır. Araştırmanın nicel verileri Bektaş, Horzum ve Ayvaz (2010) tarafından geliştirilen Öğretmenlik Uygulaması Dersi Öğretmen Adayı Akran Değerlendirmesi Ölçeği ile toplanmıştır. Nitel veriler katılımcıların hazırladıkları yansıtıcı günlüklerden elde edilmiştir. Çalışmada elde edilen nicel veriler analiz edilirken tek yönlü varyans analizi (ANOVA), Kruskal Wallis testi, Mann Whitney U testi uygulanmış, Kendall’ın uyuşum katsayısı hesaplanmıştır. Nitel veriler ise betimsel analiz tekniği kullanılarak çözümlenmiştir. Araştırma sonucunda akran değerlendirmenin öğretmen adaylarının mesleki bilgi ve becerileri üzerinde etkili olduğu, eksik ve hatalı taraflarını görmelerine ve eleştirel düşünmelerine yarar sağladığı saptanmıştır. Öğretmen adaylarının akran değerlendirmeye ilişkin görüşlerinin büyük ölçüde olumlu yönde olduğu görülmüş, değerlendirmenin objektif olmadığı konusunda olumsuz görüşlere de ulaşılmıştır. Ayrıca araştırmada değerlendirmecilerin grupların sunumlarına yapmış oldukları puanlamalar arasındaki uyumun istatistiksel olarak anlamlı ve orta düzeyde olduğu bulunmuştur. Bulgular alanyazın ilişkisinde tartışılmıştır.

Anahtar kelimeler: Akran değerlendirme, akran geribildirimi, sosyal bilgiler, öğretmen adayları

* Dr. Öğr. Üyesi, Siirt Üniversitesi, Sosyal Bilgiler Eğitimi ABD, E-posta: vtunkler@siirt.edu.tr,

Orcid ID: https://orcid.org/0000-0002-3536-968X 


\begin{abstract}
The aim of this study is to examine the effect of the peer assessment on preservice social studies teachers' professional knowledge and skills. In addition, were investigated the opinions of preservice teachers on peer assessment. The research was conducted with convergent parallel design from mixed method approaches. The study group of the research is composed of 35 preservice teachers who are studying in Social Studies Education Department of a state university. Quantitative data were obtained by using the Peer Assessment Scale for Activities of Teaching Practice Course developed by the Bektaş, Horzum and Ayvaz (2010) while qualitative data were obtained by the reflective diaries which were prepared by the participants. Quantitative data were analyzed using one-way variance analysis (ANOVA), Kruskal Wallis test and Kendall's concordance coefficient was computed. Descriptive analysis technique was applied to qualitative data. At the end of the research, it was determined that peer assessment had an effect on the professional knowledge and skills of preservice teachers. Moreover, it was found that peer assessment was useful for seeing their inadequate and incorrect aspects and to think critically. The opinions of preservice teachers on peer assessment were found to be highly positive, and were also reached negative opinions about the subject that assessment was not objective. Additionally, the study show that there was a statistically significant, and medium degree of agreement between the scores of the assessors on the presentations of the groups. Findings are discussed within the context of literature.
\end{abstract}

Keywords: Peer assessment, peer feedback, social studies, preservice teachers

\title{
Giriş
}

Ölçme ve değerlendirme alanında ortaya çıkan gelişmeler, öğrencilerin öğrenmesini geliştiren formatif değerlendirme yaklaşımlarının önemini ön plana çıkarmıştır (Bell ve Cowie, 2001; Noonan ve Duncan, 2005). Formatif değerlendirme, öğretme-öğrenme sürecinde ortaya çıkan öğrenmelere ilişkin öğrencilere ve öğretmenlere geribildirim sağlayan değerlendirmeleri ifade etmektedir (Bell ve Cowie, 2001; Noonan ve Duncan, 2005). Öğrencinin mevcut öğrenme düzeyinin belirlenmesi ve hedeflenen öğrenme düzeyine ulaşmasına yardımcı olmak için sistemli bir veri toplama süreci olarak da tanımlanan formatif değerlendirmede öğrenciler, aktif katılımcı olarak öğrenmelerinin nasıl ilerlediğinin ve gelecekte nasıl adımlar atacaklarının farkındadırlar (Heritage, 2007). Bu değerlendirme türü, başarıyı en üst düzeye çıkarmak için öğrenme gerçekleşirken öğrenmeyi geliştirmeyi amaçlamaktadır (Topping, 1998).

Formatif değerlendirmeyi işlevsel hale getirmenin bir yolu kabul edilen akran değerlendirme (Noonan ve Duncan, 2005), öğrencilerin akranlarının performansını değerlendirmelerini, ortaya çıkan ürünün düzeyini, değerini ya da kalitesini belirlemelerini sağlayan bir uygulamadır (Topping, 1998; Topping, 2009). Son ylllarda öğrenci özerkliğine artan ilgi ve önemle birlikte akran değerlendirmeye de dikkat çekilmiş, akran değerlendirme pedagojik bir değer olarak görülmüştür (Patri, 2002). Geleneksel olarak, öğrencilerin değerlendirmeye katılımı değerlendirme görevi tamamlandığında sona ererken, akran değerlendirmede değerlendirme bu süreç tamamlandıktan sonra da öğrenciler birbirlerinin çalışmalarını karşılaştırmaya ve değerlendirmeye zaman ayırmaktadır (Ballantyne, Hughes ve Mylonas, 2002). Akran değerlendirmede öğrenciler değerlendirme sürecinde yer alarak (Falchikov ve Goldfinch, 2000) 
takım çalışmasına katkılarından dolayı birbirlerini derecelendirirler ya da bireysel bir görevde ilerleme konusunda birbirlerine biçimlendirici geribildirimlerde bulunurlar (Adachi, Tai ve Dawson, 2018a). Öğrenciler birbirlerinin çalışmalarını yargılarken önceden belirlenen kriter ve standartlara başvurarak karar verirler (Adachi, Tai ve Dawson, 2018b; Falchikov ve Goldfinch, 2000), hem değerlendirmeci hem de değerlendirilen rolünü üstlenirler (Li, 2017). Bu yüzden kendilerinin ve sınıf arkadaşlarının öğrenmelerinde daha fazla sorumluluk alırlar (Johnson, 2004).

Akran değerlendirme, akran öğretiminin bir varyasyonu olup öğrencilerin birbirlerine yardımcı oldukları bir öğretim biçimi (Johnson, 2004) ve öğrenmede etkili olan değerlendirme yaklaşımıdır (Adachi vd., 2018b). Bu değerlendirme yaklaşımının en önemli bileşeni (Rotsaert, Panadero, Schellens ve Raes, 2018) ve amacı geribildirimdir (Topping, 2009). Bir öğrencinin akranına sağladığı bilgi (Rotsaert vd., 2018) olarak tanımlanan geribildirim, öğrencilerin, kendi öğrenmelerini izleyebilen, değerlendirebilen ve düzenleyebilen bağımsız öğrenenler olmalarında yarar sağlamaktadır (Ferguson, 2011'den akt. Evans, 2013). Toppinge (2009) göre, akran değerlendirmenin en önemli kalitesi bolluktur. Çünkü sinıflardaki öğrenci sayısı öğretmenlerden fazla olduğu için akranlardan gelen geribildirimler öğretmen geribildirimlerinden daha çok ve hızlı olabilmektedir. Akran geribildirimleri; doğrulayıcı, fikir verici/öneriye dayalı veya düzeltici olabilir, hataları azaltabilir, dikkatli ve tam olarak alındığında öğrenme üzerinde olumlu etki yapabilir (Topping, 2009). Geribildirim özdüzenleme becerisinin geliştirilmesi için de gereklidir (Topping, 2009).

Literatürde akran değerlendirme üzerine pek çok çalışmanın yapıldığı görülmektedir. $\mathrm{Bu}$ çalışmalarda akran değerlendirmeye yönelik algıların genellikle olumlu olduğu belirlenmiştir (Cassidy, 2006; Çoban ve Polatcan, 2018; Mika, 2006; Noonan ve Duncan, 2005; Orsmond, Merry ve Reiling, 1996; Sridharan, Muttakin ve Mihret, 2018; Uysal, 2008; Yuan ve Kim, 2018; Walker, 2001). Çeşitli araştırmalarda akran değerlendirmenin; öğrenmeyi kolaylaştırarak/destekleyerek (Adachi vd., 2018b; Ballantyne vd., 2002; Dündar, 2016) öğrencilerin akademik başarılarını arttırdığı (Çolak, 2017; Dündar, 2016; Orsmond vd., 1996; Tsivitanidou, Constantinou, Labudde, Rönnebeck ve Ropohl, 2018), eleştirel düşünmeyi (Baruah, Ward ve Jackson, 2018), empati kurmayı (Çoban ve Polatcan, 2018; Şahin ve Kalyon, 2018) ve özgüveni sağladığı (Çoban ve Polatcan, 2018; Demir, 2018) tespit edilmiştir. Ayrıca akran değerlendirme sayesinde öğrencilerin kendi çalışmalarıyla ilgili farkındalıklarının arttığı, çalışmalarını değerlendirme fırsatı buldukları (Demir, 2018; Leenknecht ve Prins, 2018; Orsmond vd., 1996; Wanner ve Palmer, 2018) ve eksik yönlerini fark edebildikleri ortaya çıkmıştır (Çoban ve Polatcan, 2018).

Akran değerlendirmenin avantajlarına rağmen güvenirlik meselesi yapılan çalışmalarda sıklıkla ele alınan konular arasında yer almaktadır. Bazı araştırmalarda, akran değerlendirmede objektifliğin sağlanamayacağı (Ballantyne vd., 2002; Dündar, 2016; Hamzadayı ve Dölek, 2017; Panadero ve Brown, 2017), değerlendiriciler arasındaki uyumun düşük olduğu (Cheng ve Warren, 2005; Dündar, 2016; Kwan ve Leung, 1996; Uyar, Demir ve Aksekioğlu, 2016) saptanmıştır. Öte yandan değerlendiricilerin değerlendirmelerinde uyumun/ilişkinin görüldüğü araştırmalarla da karşılaşılmıştır (Güneş ve Kılıç, 2016; Mika, 2006; Patri, 2002; Steensels vd., 2006). Topping 
(2003, s. 76) öğretmen değerlendirmelerinin de güvenirliğinin yüksek olmadığını, akran değerlendirmenin güvenirliğinin en azından daha yüksek olma eğiliminde olduğunu belirtmiştir.

Dochy, Segers ve Sluijsmans’n (1999) belirttiği üzere, uzun yıllar boyunca yükseköğretimin ana hedefi öğrencileri belirli bir alanda bilgili hale getirmek olmuştur. Bu sebeple, temel bilgi deposu oluşturmak önemli konular arasında yer almıştır. Günümüzde çevrimiçi ve harmanlanmış öğrenme, öğrencinin öğrenme sürecine etkin katılımı, öğrenci merkezli öğretim, yaşam boyu öğrenme gibi pedagojik değişimler ortaya çıkmıştır (Wanner ve Palmer, 2018). Yaşanılan bu gelişmeler üniversitelerde değerlendirme anlayışında değişikliğe yol açmış, sınıf içi değerlendirmelerde akran değerlendirmenin kullanılmasına yönelik ilgi artırmıştır (Wanner ve Palmer, 2018). Searby ve Ewers (1997) yükseköğretimde akran değerlendirmenin yapılmasına en önemli gerekçe olarak öğrencilerin eleştirel düşünmelerini ve öğrenmelerini kontrol etmelerini sağladığı, böylece öğretim elemanına olan bağımlılığı azalttığını ifade etmişlerdir. Değerlendirme, öğrenme için ana motivasyon kaynağıdır ve öğrenenin öğrenmesinin kapsamına ve kalitesine ilişkin yargıya ulaşma işlemidir (Wanner ve Palmer, 2018). Yükseköğretimde aktif öğrenmeyi destekleyen akran değerlendirme, öğrenciler arasında etkili ve işbirlikli öğrenme ortamı kurarak onlara geribildirim sayesinde birbirlerinden öğrenebilecekleri bir platform sunmaktadır (Baruah vd., 2018). Özetle akran değerlendirme, üniversitelerde büyük ölçüde öğrencilerin çalışmalarına not verme ve öğrencilerin daha etkili öğrenmelerini sağlamaya yönelik (Hanrahan ve Isaacs, 2001) tamamlayıcı değerlendirme yöntemi olarak kullanılmaktadır (Wen ve Tsai, 2006).

Artan ilgiye rağmen akran değerlendirmenin hâlâ yükseköğretimdeki değerlendirme uygulamalarının gerisinde kaldığı (Wanner ve Palmer, 2018), öğrencilerin büyük çoğunluğunun bu değerlendirme sürecine katılamadıkları (Yuan ve Kim, 2018) alanyazında vurgulanmaktadır. Hâlbuki akran değerlendirmenin (Akılll, 2007; Biri, 2014; Yurtseven ve Altun, 2018) ve akran desteğinin mesleki gelişime katkı sağladığı bir gerçektir (Cohen ve Nath, 2006; Yuan ve Kim, 2018). Yükseköğretim kurumlarının yeterliğe dayalı öğrenme talebi dikkate alındığında, akran değerlendirmenin öğretmen eğitiminde öğrenme aracı olarak kullanması öğretmen adaylarının mesleki hayatlarında gerekli olan becerileri kazanmaları noktasında onlara destek sunacaktır (Sluijsmans ve Prins, 2006). Bu bakımdan öğretmen adaylarının eğitiminde akran değerlendirmenin kullanılması gereklidir. Bu çalışmanın amacı, akran değerlendirmenin sosyal bilgiler öğretmen adaylarının mesleki bilgi ve becerilerine etkisinin incelenmesi, öğretmen adaylarının akran değerlendirme hakkındaki görüşlerinin belirlenmesidir.

\section{Yöntem}

\section{Araștırma deseni}

Araştırmada karma yöntem araştırma desenlerinden yakınsayan paralel desen kullanılmıştır. $\mathrm{Bu}$ desende, nicel ve nitel veriler eş zamanlı toplanarak ayrı ayrı analiz edilmekte, iki veri setinin analizinden elde edilen sonuçlar birlikte yorumlanmaktadır (Creswell ve Clark, 2014). Araştırmanın nicel boyutunda tarama modeli uygulanmıştır. Veri toplama aracı olarak anket ya da 
ölçeklerin kullanıldığı tarama modeliyle mevcut durum betimlenmeye çalışılmaktadır (Karasar, 2012). Nitel boyut ise durum çalışması deseninde kurgulanmıştır. Araştırmada durum çalışması deseninin kullanım amacı, sosyal bilgiler öğretmen adaylarının akran değerlendirmenin mesleki bilgi ve becerilerine etkisi hakkındaki görüşlerini ortaya koymaktır.

\section{Çalışma grubu}

Araştırmanın çalışma grubunu, Türkiye'de bir devlet üniversitesinin Sosyal Bilgiler Eğitimi Anabilim Dalında son sınıfta öğrenim gören 35 öğretmen adayı (23 kadın, 12 erkek) oluşturmaktadır. Katılımcıların belirlenmesinde amaca yönelik örnekleme yöntemi kullanılmış, araştırma, kolay ulaşılabilen ve çalışmaya katılmaya istekli öğretmen adayları ile yürütülmüştür.

\section{Verilerin toplanması ve analizi}

Araştırmaya katılan öğretmen adaylarının ders anlatımlarını değerlendirmek için Öğretmenlik Uygulaması Dersi Öğretmen Adayı Akran Değerlendirmesi Ölçeği uygulanmıştır. Bektaş, Horzum ve Ayvaz (2010) tarafından geliştirilen Öğretmenlik Uygulaması Dersi Öğretmen Adayı Akran Değerlendirmesi Ölçeği (ÖUDÖAADÖ) için yapılan açımlayıcı faktör analizi sonucunda 5 faktörlü bir yapı elde edilmiştir. Ölçekte yer alan faktörler "öğretim süreci", "iletişim kurma ve değerlendirme", "derse hazırlama ve dersi ilişkilendirme", "sınıf yönetimi" ve "geribildirim" şeklindedir. Beşli likert tipinde hazırlanan bu ölçekteki 29 maddenin faktör yük değerleri 0.30-0.86 arasında değişmektedir. Ölçekte yer alan beş faktör toplam varyansın \%50'sini açıklamaktadır. Ölçeğin geneline ilişkin toplam iç tutarlık katsayısı .92 olarak bulunmuştur. Ölçeğin alt boyutlarına ilişkin iç tutarlılık kat sayıları; birinci alt faktör için .81, ikinci alt faktör için .78, üçüncü alt faktör için .78, dördüncü alt faktör için .68 ve beşinci alt faktör için .67 olarak bulunmuştur. Ölçekten alınabilecek en düşük puan 29, en yüksek puan $145^{\prime}$ tir. Ölçeğin bu araştırma kapsamında hesaplanan Cronbach Alpha değerleri .60-.89 arasında değişmektedir.

Nicel verilerin çözümlenmesi aşamasında ilk olarak varsayımların karşılanıp karşılanmadığ sınanmıştır. Grup değişkenine göre verilerin ölçeğin alt boyutlarına göre dağllımına bakılmış, dağılımın normalliğinin saptanmasında Shapiro-Wilk testinden yararlanılmıştır. Verilerin normal dağılım gösterdiği alt boyutlarda tek yönlü varyans analizi (ANOVA) yapılırken, normal dağılım olmayan alt boyutlarda Kruskal Wallis testi kullanılmıştır. F testinde gruplar arası anlamlı farkın hangi gruptan kaynaklandığını belirlemek için Tukey HSD testi uygulanmıştır. Ayrıca grupların ders anlatımlarının dört farklı değerlendirmeci tarafından değerlendirilmesi ile ulaşılan sonuçlar arasındaki tutarlılık derecesi, parametrik olmayan bir teknik olan Kendall’n uyuşum katsayısı ile hesaplanmıştır. Tüm bu işlemler SPSS 21 paket programı aracılığıyla yapılmıştır.

Öğretmen adaylarının akran değerlendirmeye yönelik görüşlerini belirlemek için onlardan sunum öncesi-sırası-sonrası izlenimlerini belirtecekleri yansıtıcı günlük hazırlamaları istenilmiş, toplanan günlükler betimsel analiz tekniğiyle çözümlenmiştir. Analiz sürecinde katılımcıların akran değerlendirmeye ilişkin görüşleri (olumlu ve olumsuz görüşler) kodlanmış, ardından bu kodları belirli kategoriler altında toplayabilen alt temalar bulunmuş ve son aşamada ulaşılan bulgular yorumlanmıştır (Yıldırım ve Şimşek, 2016). Araştırmada temaların belirlenmesinde 
literatürdeki çalışmalardan yararlanılmıştır. Katılımcıların alt temalara ilişkin görüşlerinden bazıları ve atıf sayıları (frekans) tablolarda sunulmuştur. Katılımcıların görüşlerinden doğrudan alıntılar yapılırken katılımcının ismi yerine kod numaraları (K1, K23...) kullanılarak kimlikleri gizli tutulmaya çalışılmıştır. Araştırmanın geçerliğini sağlamak için katılımcıların görüşlerinden doğrudan alıntılar yapılmıştır. Güvenirliğin sağlanması hususunda ise sosyal bilgiler eğitimi alanında nitel araştırma deneyimi ve doktora unvanına sahip olan başka bir araştırmacıdan yardım alınmış, kodlamalar ve ulaşılan temalar bu araştırmacı tarafından da kontrol edilerek uzlaşı sağlanmıştır.

\section{Uygulama süreci}

Araştırma verileri, 2018-2019 güz döneminde Sosyal Bilgiler Eğitimi Anabilim Dalında Özel Öğretim Yöntemleri II ve Okul deneyimi dersini alan öğretmen adaylarından elde edilmiştir. İlgili anabilim dalında araştırmacının yürüttüğü Özel Öğretim Yöntemleri II dersinde öğretmen adayları altı kişiden oluşan toplamda beş gruba ayrılmış, her bir gruba sosyal bilgiler öğretim programında yer alan farklı bir beceri (problem çözme, eleştirel düşünme, mekânı algılama, kalıp yargı ve önyargıyı fark etme, kanıt kullanma becerisi) dağıtılmıştır. Gruplar sorumlu oldukları beceri ile ilgili kazanım belirlemiş ve etkinlikle birlikte beceriyi ayrıntılı bir şekilde tanımlayan rapor hazırlamışlardır. Gruplardan (tüm grup üyeleri) ayrıca akran değerlendirmeye yönelik görüşlerini yansıtacakları yansıtıcı günlük tutmaları istenmiştir. Gruplar akran değerlendirme destekli sunumlar gerçekleştirmiş, yapılan bu sunumlarda ÖUDÖAADÖ kullanılmadan sadece sözlü akran geribildirimlerinde bulunulmuştur. Akran geribildirimleri göz önüne alınarak, Okul Deneyimi dersi kapsamında grup üyelerinden biri tarafından uygulama okulunda tekrarlanan sunum (40 dakika), araştırmacının kendisi ile grupta yer almayan üç akran tarafından ÖUDÖAADÖ kullanılarak değerlendirilmiştir. Sunumların tamamlanmasının ardından yansıtıcı günlükler toplanmıştır.

\section{Bulgular}

Bu bölümde araştırmanın bulguları araştırmanın problemi doğrultusunda sunulmuştur. Bunun için öncelikle nicel verilerden ulaşılan bulgulara, ardından nitel verilerden elde edilen bulgulara yer verilmiştir.

\section{Akran değerlendirmenin öğretmen adaylarının mesleki bilgi ve becerilerine etkisine ait bulgular}

Akran değerlendirmenin öğretmen adaylarının mesleki bilgi ve becerilerine etkisine ait bulgulara geçilmeden önce değerlendirmecilerin grupların sunumlarına atadıkları puanların tutarlılığına ilişkin sonuçlara değinilmesinde yarar vardır.

Dört değerlendirmecinin aynı koşullar altında her bir grubu bağımsız olarak puanlamasına ilişkin elde edilen puanlar arasındaki tutarlılık derecesi Kendall’’n uyuşum katsayısı ile hesaplanmıştır. Bulgular Tablo 1'de sunulmuştur. 
Tablo 1

Kendall'ın Uyuşum Katsayıları (W)

\begin{tabular}{cccc}
\hline Grup & W & $\chi^{2}$ & p \\
\hline Grup 1 & .589 & 62.974 & $.000^{*}$ \\
Grup 2 & .508 & 56.905 & $.001^{*}$ \\
Grup 3 & .471 & 52.719 & $.003^{*}$ \\
Grup 4 & .477 & 53.422 & $.003^{*}$ \\
Grup 5 & .464 & 51.953 & $.004^{*}$ \\
\hline & & &
\end{tabular}

Tablo 1 incelendiğinde, dört değerlendirmecinin grupların sunumlarına yapmış oldukları puanların uyuşum katsayısı Grup 1 için $\mathrm{W}=.589\left(\chi^{2}=62.974 ; \mathrm{p}<.05\right)$, Grup 2 için $\mathrm{W}=.508$ $\left(\chi^{2}=56.905 ; \mathrm{p}<.05\right)$, Grup 3 için $\mathrm{W}=.471\left(\chi^{2}=52.719 ; \mathrm{p}<.05\right)$, Grup 4 için $\mathrm{W}=.477\left(\chi^{2}=53.422\right.$; $\mathrm{p}<.05)$ ve Grup 5 için $\mathrm{W}=.464\left(\chi^{2}=51.953 ; \mathrm{p}<.05\right)$ olduğu görülmektedir. Bu bulgulara dayalı olarak her bir puanlayıcının aynı koşullar altında grup değerlendirmeleri arasındaki uyumun istatistiksel olarak anlamlı ve orta düzeyde olduğu söylenilebilir.

Tablo 2

Grup Değişkenine Göre Öğrencilerin Ölçeğin Öğretim Süreci, İletişim Kurma Ve Değerlendirme Ve Derse Hazırlama Ve Dersi İlişkilendirme Alt Boyutlarına İlişkin Tek Yönlü Varyans Analizi (ANOVA) Sonuçları

\begin{tabular}{|c|c|c|c|c|c|c|c|c|}
\hline Boyutlar & Gruplar & $\mathrm{N}$ & $\mathrm{x} \rrbracket$ & ss & df & $\mathbf{F}$ & $\mathrm{p}$ & Anlamlı Fark \\
\hline \multirow{5}{*}{ Öğretim Süreci (ÖS) } & Grup 1 & 4 & 27.75 & 7.45 & \multirow{5}{*}{15} & \multirow{5}{*}{1.005} & \multirow{5}{*}{.435} & \multirow{5}{*}{ Anlamsız } \\
\hline & Grup 2 & 4 & 30.25 & 7.76 & & & & \\
\hline & Grup 3 & 4 & 33.50 & 5.80 & & & & \\
\hline & Grup 4 & 4 & 34.50 & 5.06 & & & & \\
\hline & Grup 5 & 4 & 34.50 & 1.73 & & & & \\
\hline \multirow{5}{*}{$\begin{array}{c}\text { İletişim Kurma ve } \\
\text { Değerlendirme (İKD) }\end{array}$} & Grup $1(1)$ & 4 & 14.50 & 1.29 & \multirow{5}{*}{15} & \multirow{5}{*}{7.056} & \multirow{5}{*}{$.002^{*}$} & \multirow{5}{*}{$1-3,1-5$} \\
\hline & Grup $2(2)$ & 4 & 19.25 & 4.92 & & & & \\
\hline & Grup $3(3)$ & 4 & 22.25 & 2.06 & & & & \\
\hline & Grup $4(4)$ & 4 & 20.00 & 3.55 & & & & \\
\hline & Grup 5(5) & 4 & 25.75 & 2.36 & & & & \\
\hline \multirow{5}{*}{$\begin{array}{l}\text { Derse Hazırlama ve } \\
\text { Dersi İlişkilendirme } \\
\text { (DHDİ) }\end{array}$} & Grup $1(1)$ & 4 & 11.75 & 4.99 & \multirow{5}{*}{15} & \multirow{5}{*}{4.671} & \multirow{5}{*}{$.012^{*}$} & \multirow{5}{*}{$1-4,1-5$} \\
\hline & Grup 2(2) & 4 & 15.00 & 2.58 & & & & \\
\hline & Grup $3(3)$ & 4 & 19.50 & 2.88 & & & & \\
\hline & Grup 4 (4) & 4 & 20.75 & 4.64 & & & & \\
\hline & Grup 5 (5) & 4 & 20.25 & 2.06 & & & & \\
\hline \multicolumn{9}{|c|}{${ }^{*} p<.05 ; \mathrm{N}=$ Değerlendirmeci sayıs1; $\mathrm{S}_{\text {Кт-ко }}=143.300-35.825 ; \mathrm{I}_{\mathrm{K}} \mathrm{KT}_{\mathrm{KO}}=273.300-68.325 ; \mathrm{DHDI}{ }_{\mathrm{KT}-\mathrm{KO}}=245.700-61.425$} \\
\hline
\end{tabular}


anlamlı fark görülmemiştir ( $\mathrm{p}>$.05). Tek yönlü varyans analizinden elde edilen bu kümülâtif farklılığın kaynağının iletişim kurma ve değerlendirme ile derse hazırlama ve dersi ilişkilendirme alt boyutlarında hangi gruplar arasında ortaya çıktığını belirlemek için öncelikle varyansların homojenliğine bakılmış, her iki alt boyutta da varyansların homojen olduğu belirlenmiştir (p>.05). $\mathrm{Bu}$ çerçevede post hoc tekniklerden Tukey HSD testi yapılmıştır. Analiz sonuçları incelendiğinde, iletişim kurma ve değerlendirme alt boyutunda Grup 1'in puan ortalaması ( $\mathrm{x} \rrbracket=14.50)$ Grup 3

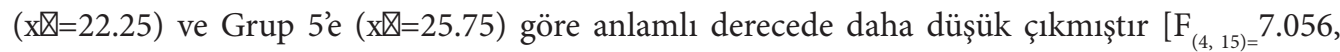
$\mathrm{p}<.05$ ]. Derse hazırlama ve dersi ilişkilendirme alt boyutunda ise Grup 1'in puan ortalaması

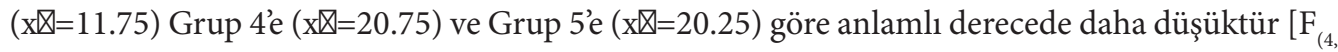
15) $=4.671, \mathrm{p}<.05]$.

\section{Tablo 3}

Grup Değişkenine Göre Ölçeğin Öğretim Süreci ve Derse Hazırlama ve Dersi İlişkilendirme Alt Boyutlarına İlişkin Kruskal Wallis Testi Sonuçları

\begin{tabular}{l|c|c|c|c|c|c}
\hline \multicolumn{2}{c}{ Alt Boyutlar } & Gruplar & N & Sira Ort. & sd & \multirow{2}{*}{$\chi^{2}$} \\
\hline \multirow{3}{*}{ Sinıf Yönetimi } & Grup 1 & 4 & 7.38 & & & \\
& Grup 2 & 4 & 10.75 & & & \\
& Grup 3 & 4 & 8.88 & 4 & 5.326 & .255 \\
& Grup 4 & 4 & 9.38 & & & \\
& Grup 5 & 4 & 16.13 & & & \\
\hline \multirow{5}{*}{ Geribildirim } & Grup 1 & 4 & 4.00 & & & \\
& Grup 2 & 4 & 11.88 & & & \\
& Grup 3 & 4 & 9.63 & \multirow{2}{*}{4} & \multirow{2}{*}{8.921} & .063 \\
& Grup 4 & 4 & 11.13 & & & \\
& Grup 5 & 4 & 15.88 & & & \\
\hline
\end{tabular}

$\mathrm{N}=$ Değerlendirmeci sayıs1

Tablo 3'te grupların sınıf yönetimi ve geribildirim alt boyutları puanlarının Kruskal Wallis Testi sonuçlarına yer verilmiştir. Analiz sonuçlarına göre grupların sınıf yönetimi $\left[\chi^{2}\right.$ ( $\mathrm{sd}=4$, $\mathrm{n}=20)=5.326, \mathrm{p}>.05]$ ve geribildirim $\left[\chi^{2}(\mathrm{sd}=4, \mathrm{n}=20)=8.921, \mathrm{p}>.05\right]$ alt boyutlarına ait puanlarının anlamlı şekilde farklılaşmadığı saptanmıştır.

\section{Öğretmen adaylarmın akran değerlendirmeye ilişkin olumlu görüssleri}

Araştırmanın katılımcıları tarafından hazırlanan yansıtıcı günlükler incelendiğinde, akran değerlendirmenin "öğretmenlik becerileri kazandırma ve geliştirme, bireye eksik ve hatalı yönlerini gösterme, eleştirel düşünmeyi sağlama” yönünde olumlu katkılarının olduğu görülmektedir Tablo 4'te bu nitelikteki bulgulara ilişkin temalar ile katılımcılardan bazılarının görüşleri yer almaktadır. Ayrıca bulgulara değinilirken tablodaki öğrenci görüşlerine ek olarak farklı öğrenci görüşlerinden de doğrudan alıntılar yapılmış, böylece içerik zenginleştirilmeye çalışılmıştır. 


\section{Tablo 4}

Öğretmen Adaylarının Akran Değerlendirmeye İlişkin Olumlu Görüşleri

\begin{tabular}{|c|c|c|c|}
\hline Temalar & Alt tema(lar) & $f^{*}$ & İfade edilen görüşlerden bazıları \\
\hline \multirow{4}{*}{$\begin{array}{l}\text { Öğretmenlik } \\
\text { Becerileri } \\
\text { Kazandırma ve } \\
\text { Geliştirme }\end{array}$} & $\begin{array}{l}\text { Öğretim süreci } \\
\text { ile ilgili beceriler }\end{array}$ & 16 & $\begin{array}{l}\text { "Sınıfta nasıl davranmamız gerektiğini, araç ve gereç kullanımının } \\
\text { ne derece faydalı olacağını materyallerin dersi somutlaştırmada } \\
\text { önemli olduğunu, zamanı etkin kullanmamız gerektiğini, farklı } \\
\text { öğrenme stillerini ve öğrencilerin hazırbulunuşluk düzeyini göz ardı } \\
\text { etmememiz gerektiğini öğretti." (K14) }\end{array}$ \\
\hline & $\begin{array}{l}\text { Planlamayla ilgili } \\
\text { beceriler }\end{array}$ & 14 & $\begin{array}{l}\text { "Bir öğretmen dersi işlerken, değerlendirme yaparken, ders planı } \\
\text { hazırlarken ne yapmalı? Nasıl yapmalı? Bunların cevabını aldım. } \mathrm{Bu} \\
\text { ders beni birkaç adım öne itti." (K8) }\end{array}$ \\
\hline & $\begin{array}{l}\text { Sinıf yönetimiyle } \\
\text { ilgili beceriler }\end{array}$ & 8 & $\begin{array}{l}\text { "Dersimizde akran değerlendirmeyi uygulamamız sayesinde sınıfta } \\
\text { bir sorun çıktığı zaman o sorunla baş etmeyi, sınıf yönetimini } \\
\text { sağlarken nelerin yapılıp yapılmamasını öğrendik ve ilerde } \\
\text { öğretmenlik mesleğimizde uygulayabileceğiz." (K19) }\end{array}$ \\
\hline & $\begin{array}{l}\text { İletişim } \\
\text { kurmayla ilgili } \\
\text { beceriler }\end{array}$ & 2 & $\begin{array}{l}\text { "Bir öğretmenin nasıl, ne şekilde ve öğrencilerle diyaloğu, iletişimi, } \\
\text { ses tonu nasıl olması gerektiğini öğrendim." (K17) }\end{array}$ \\
\hline $\begin{array}{l}\text { Bireye Eksik ve } \\
\text { Hatalı Yönlerini } \\
\text { Gösterme }\end{array}$ & & 12 & $\begin{array}{l}\text { "Kendi grup sunumumuzun eksik olan, gözden kaçırdığımız } \\
\text { noktaların neler olduğunu çok iyi fark etmiş oldum. Diğer yapılan } \\
\text { sunumlarda da aynı şekilde arkadaşlarımını eksik yönlerini görüp } \\
\text { ona göre planlamamızı yapmaya imkan verdi." (K29) }\end{array}$ \\
\hline $\begin{array}{l}\text { Eleştirel } \\
\text { Düşünmeyi } \\
\text { Sağlama }\end{array}$ & & 5 & $\begin{array}{l}\text { "Akran değerlendirme eleştirel düşünme ve yorum yapma kabiliyeti } \\
\text { geliştirdi." (K16) }\end{array}$ \\
\hline
\end{tabular}

Tablo 4'ten anlaşılacağı üzere öğretmen adaylarının akran değerlendirmeyle ilgili görüşleri farklılık göstermektedir. Katılımcılar akran değerlendirmenin; planlama, öğretim süreci, sınıf yönetimi ve iletişim kurma ile ilgili öğretmenlik becerilerini kazandırdığ ve geliştirdiği yönünde görüş belirtmişlerdir. Öğretmenlik becerileri noktasında üzerinde en çok durulan becerinin “öğretim süreci ile ilgili beceriler” olduğu dikkat çekmektedir. Katılımcılar akran değerlendirme sayesinde çeşitli yöntem ve teknikleri uygun bir şekilde kullanmayı, kazanımın düzeyine göre ve öğrencilerin derse aktif bir şekilde katılımı için etkinlikler düzenlemeyi, derste öğretim materyali kullanmanın yararını öğrendiklerini ifade etmişlerdir. K1 kodlu katılımcıdan yapılan “Ders içerisinde öğretimi kalıcı ve etkin kılmak için; hangi yöntem-teknikleri kullanacă̆ımı ve ne zaman kullanacă̆ımı öğrendim.” şeklindeki alıntıya göre, akran değerlendirme öğrencilerin öğretim yöntem ve teknikleri hakkındaki yeterliklerini geliştirmelerine katkı sağlamaktadır.

Yansıtıcı günlüklerde değinilen bazı ifadelerde akran değerlendirmenin planlamayla ilgili becerilerin kazanılmasına katkıları olduğu anlaşılmaktadır. Katılımcılar akran değerlendirme aracılığıyla ders planının nasıl yapıldı̆̆ını, ders anlatımında nelere dikkat edildiğini, yani öğrenme içeriğinin nasıl ve ne şekilde sunulacağını anladıklarını dile getirmişlerdir. Katılımcılardan K6'nın görüşü şu şekildedir: "Bu uygulama sayesinde bir ders konusunun nasıl ne şekilde, materyaller, etkinlikler dahilinde nasıl anlatacă̆ımızı ögrendik.” 
Akran değerlendirmenin mesleki becerileri kazandırma ve geliştirme hususundaki yararlarından biri olarak dile getirilen bulgular arasında sınıf yönetimiyle ilgili beceriler yer almaktadır. Katılımcı görüşleri incelendiğinde, bu uygulama ile sınıfta istenmeyen öğrenci davranışlarının önüne nasıl geçileceği, öğrencilerin derse dikkatini çekme ve ilgisini artırmanın önemini kavradıkları belirlenmiştir. Katılımcılardan K5 "Ders anlatırken öğrenciyi nasıl derse çekebileceğimi yani kısacası dersi süsleyerek anlatmanın öğrencinin derse olan ilgisini artırdı̆̆ını anladım.” sözleriyle bu duruma örnek oluşturmaktadır. Akran değerlendirmenin öğrencilerin iletişim kurmayla ilgili becerileri kazandırdığı araştırmadan elde edilen bir diğer bulgudur. Katılımcılara göre akran değerlendirme öğrencilerle etkili iletişim ve ilişki kurmayı sağlamaktadır.

Katılımcılar, değerlendirme sırasında yapılan dönütlerin (kendileri ve akranları için) yansıtıcı yönünü (bireye eksik ve hatalı yönlerini gösterme) vurgulamışlardır. Bu kapsamda ele alınan katılımcı görüşlerine göre, sunumları izleme ve sunumlara ilişkin değerlendirmelerde bulunma kendilerinin eksiklerini ve hatalarını görmelerine, bu eksikleri tamamlayıp hataları düzelterek sunumu yeniden planlamalarına yarar sağlamaktadır. Katılımcılardan K7 “Akran değerlendirme aslında çok güzel bir yöntem çünkü insana eksik yönlerini gösteriyor.” ve K35’in “Anlatan arkadaş hangi seviyede olduğunu görüyor ve hatasını fark edip daha iyisini nasıl yapacă̆ını kestirebiliyor. Neyi daha iyi ve nasıl yapacağını öğreniyor.” şeklindeki görüşleri akran değerlendirmenin bireye eksik ve hatalı yönlerini gösterdiğine işaret etmektedir.

Akran değerlendirmenin olumlu yanları arasında belirtilen durumlardan biri de eleştirel düşünmeyi sağlamasıdır. Katılımcılar akran değerlendirme yardımıyla görüşlerini rahat bir şekilde dile getirdiklerini ve eleştiriye açık olmayı öğrendiklerini ifade etmişlerdir. K31'in “Akran değerlendirmenin olumlu yönü ise bizlere eleştiri yapmayı öğretiyor olmasıdır.” ifadesi bu konuya açılık getirmektedir.

\section{Öğretmen adaylarının akran değerlendirmeye ilişkin olumsuz görü̈sleri}

Öğretmen adaylarının akran değerlendirmenin olumsuz taraflarına yönelik görüşleri "değerlendirmenin objektif olmaması" teması altında ele alınmıştır (Tablo 5). Katılımcılar, arkadaşlık ilişkilerinin değerlendirmenin önüne geçtiğini belirterek yapılan değerlendirmelerin objektifolmadığına dikkat çekmişlerdir. Akran değerlendirmenin bu özelliğinin değerlendirmenin güvenirliğini düşürdügünü söyleyen K30’un görüşü şöyledir: “Bazı arkadaşlarımızın yaptıkları sunumlarına karşı objektif değil de sübjektif olarak eleştirilerde bulunuldu. Bu da akran değerlendirmenin güvenirliğini düşürdüğünü düşünüyorum.”

\section{Tablo 5}

Öğretmen Adaylarının Akran Değerlendirmeye İlişkin Olumsuz Görüşleri

\begin{tabular}{|c|c|c|}
\hline Tema & $f^{*}$ & İfade edilen görüşlerden bazıları \\
\hline $\begin{array}{l}\text { Değerlendirmelerin } \\
\text { Objektif Olmaması }\end{array}$ & 10 & $\begin{array}{l}\text { "Sınıf arkadaşlarımızın yaptığı yorumlara baktığımda tarafsız olduklarını } \\
\text { düşünmüyorum. Çoğu kişi sevdiği, samimi olduğu kişilere olumlu yorumlar } \\
\text { yapıyorlardı. Sevmediği kişilere de olumsuz yorumlar yapıyorlardı. Bu yüzden ben } \\
\text { akran değerlendirmesini objektif bulmuyorum." (K28) }\end{array}$ \\
\hline
\end{tabular}




\section{Tartışma ve Sonuç}

$\mathrm{Bu}$ çalışmada, akran değerlendirmenin sosyal bilgiler öğretmen adaylarının mesleki bilgi ve becerilerine etkisi, öğretmen adaylarının akran değerlendirme hakkındaki görüşleri incelenmiştir. Elde edilen nicel bulgulara göre akran değerlendirmenin öğretmen adaylarının mesleki bilgi ve becerileri üzerinde etkili olduğu belirlenmiştir. İletişim kurma ve değerlendirme ile derse hazırlama ve dersi ilişkilendirme becerilerinde grupların puan ortalamaları arasında anlamlı farklılık görülürken, öğretim süreci, sınıf yönetimi ve geribildirim becerileri puan ortalamalarında anlamlı farklılık ortaya çıkmamıștır. Ancak ilerleyen haftalarda ders anlatımı yapan grupların puan ortalamalarında ilk gruplara göre artış olduğu tespit edilmiştir. Öğretmen adayları tarafından hazırlanan yansıtıcı günlüklerin analizi sonucu ulaşılan nitel bulgular bu bulguları destekler niteliktedir. Nitekim öğretmen adayları akran değerlendirmenin; planlama, öğretim süreci, sınıf yönetimi ve iletişim kurma ile ilgili öğretmenlik becerilerini kazandırdı̆̆g ve geliştirdiği yönünde görüş belirtmişlerdir. Öğretmenlik becerileri noktasında üzerinde en çok durulan becerinin 'öğretim süreci ile ilgilibeceriler’ olduğu dikkat çekmektedir. Elde edilen bulgular literatürdeki benzer çalışmaların sonuçları ile paralellik göstermektedir (Akıllı, 2007; Biri, 2014; Şen, 2010; Yurtseven ve Altun, 2018). Akıllı (2017). Biri (2014) yapmış olduğu araştırmada akran değerlendirme yönteminin öğretmen adaylarının planlama, iletişim kurma ve değerlendirme, sınıf yönetimi, derse hazırlama ve dersi ilişkilendirme ve öğretim süreci becerilerine katkı sağladığı sonucuna ulaşmıştır. Akıllı (2007) ile Yurtseven ve Altun'un (2018) çalışmalarında da akran değerlendirmenin mesleki gelişime yarar sağladığı ortaya çıkmıştır. Literatürde akran değerlendirmenin öğrencilerin iletişim (Topping, 2009), değerlendirme (Cassidy, 2006; Song, Guo ve Gehringer, 2017; Şahin ve Kalyon, 2018), takım çalışması/koordinasyonu (Baruah vd., 2018; Topping, 1998) ve empati becerisini geliştirdiği (Şahin ve Kalyon, 2018; Topping, 1998), özgüvenini (Çoban ve Polatcan, 2018; Demir, 2018) ve motivasyonunu arttırdığı belirtilmektedir (Topping, 1998).

Çalışmanın bulguları, akran değerlendirme sırasında yapılan geribildirimlerin yansıtıcı yönünü (bireye eksik ve hatalı yönlerini gösterme) ortaya koymuştur. Öğretmen adayları diğer grupların sunumlarını izlemenin ve sunumlara ilişkin değerlendirmelerde bulunmanın eksiklerini ve hatalarını görmelerine, bu eksikleri tamamlayıp hataları düzelterek sunumu yeniden planlamalarına olanak sağladığını ifade etmişlerdir. Farklı katılımcılar üzerinde yapılan araştırmalarda, akran değerlendirme sayesinde bireylerin kendi çalışmalarıyla ilgili farkındalık sahibi oldukları (Akpınar ve Kranda, 2016; Demir, 2018; Leenknecht ve Prins, 2018; Orsmond vd., 1996), yetersiz yönlerini fark edebildikleri (Akpınar ve Kranda, 2016; Çoban ve Polatcan, 2018; Demir, 2018; Izgar ve Akturk, 2018) ve çalışmalarını geliştirebildikleri tespit edilmiştir (Wanner ve Palmer, 2018). Akran değerlendirmenin en önemli amacı (Topping, 2009) ve bileşeni geribildirimdir (Rotsaert vd., 2018). Geribildirim etkili öğrenmeyle ilişkilidir (Topping, 1998). Bu araştırmada öğretmen adaylarının mesleki bilgi ve becerilerinin gelişmesinde geribildirimin rolü büyük önem taşımaktadır. Tünkler ve Güven (2019) yaptıkları araştırma sonucunda geribildirimin öğretmen adaylarının ölçme-değerlendirme becerilerinin gelişmesinde etkili olduğu saptanmıştır. Murray, McGill, Thompson ve Toohey (2017) üniversite öğrencileri üzerinde gerçekleştirdikleri 
çalışmalarında öğrenciler geribildirimlerin öğrenmeye katkı sunduğunu belirtmişlerdir. Rotsaert vd. (2018) ile Cassidy’nin (2006) araştırma bulguları öğrencilerin geribildirimi değerli gördüklerini göstermektedir. Benzer sonuçlar Yuan ve Kim’in (2018) araştırmasında da ortaya çıkmış, öğrenciler akran değerlendirmeyi değerli bulma nedenleri arasında birden fazla kişiden gelen geribildirimlerin faydasını ifade etmişlerdir.

Çalışmada ulaşılan bir başka bulgu da, akran değerlendirmenin eleş̧trel düşünmeyi sağlamasıdır. Öğretmen adayları akran değerlendirme yardımıyla görüşlerini rahat bir şekilde dile getirdiklerini ve eleştiriye açı olmayı öğrendiklerini belirtmişlerdir. Bu bulguyu destekler nitelikte çalı̧̧malara rastlanılmıştır. Bu çalışmalarda akran değerlendirmenin öğrencilerin eleştirel düşünme becerilerini geliştirdiği saptanmıştır (Akpınar ve Kranda, 2016; Baruah vd., 2018; Biri, 2014; Izgar ve Akturk, 2018; Searby ve Ewers, 1997). Araştırma bulguları genel olarak öğretmen adaylarının akran değerlendirmeye yönelik görüşlerinin olumlu olduğunu göstermektedir. Önceki araştırmalarda da lise (Orsmond vd., 1996), üniversite öğrencileri (Cassidy, 2006; Çoban ve Polatcan, 2018; Planas-Lladó vd., 2018; Sridharan vd., 2018; Yuan ve Kim, 2018; Walker, 2001; Wen ve Tsai, 2006) ve öğretmenlerin akran değerlendirmeyle ilgili olumlu görüşe sahip oldukları ortaya konmuştur (Noonan ve Duncan, 2005). Araştırmada elde edilen bulgular doğrultusunda akran değerlendirmeye ilişkin olumsuz görüşlerin değerlendirmenin objektif olmadığı yönünde olduğu bulunmuştur. Öğretmen adayları buna gerekçe olarak arkadaşlı ilişkilerinin değerlendirmenin önüne geçtiğini ileri sürmüşlerdir. İlgili alanyazındaki araştırmalarda öğrencilerin (Ballantyne vd., 2002; Dündar, 2016; Güzel, 2018) ve öğretmenlerin akran değerlendirmede objektifliğin sağlanamayacağ yönünde kaygılarının olduğu belirlenmiştir (ArchMiller, Fieberg, Walker ve Holm, 2017; Hamzadayı ve Dölek, 2017; Panadero ve Brown, 2017). Özdemir ve Erdem (2017) çalışmalarında akran değerlendirmede arkadaşlık ilişkilerinin etkisi incelenmiş, sonuç olarak arkadaşlık ilişkilerinin değerlendirme üzerinde etkili olduğu ortaya çıkmıştır.

Araştırma kapsamında her bir değerlendirmecinin grupların sunumlarına yapmış oldukları puanlamalar arasındaki uyumun istatistiksel olarak anlamlı ve orta düzeyde olduğu belirlenmiştir. Kwan ve Leung (1996) ile Dündar (2016) çalışmalarında öğrencilerin akranlarına verdikleri puanların uzman puanları ile orta düzeyde uyum gösterdiğini ortaya koymuştur. Benzer şekilde çeşitli araştırmalarda da akran değerlendirmeleri ile uzman değerlendirmeleri arasında uyum ortaya çıkmıştır (Cheng ve Warren, 2005; Mika, 2006; Patri, 2002; Steensels vd., 2006).

Sonuç olarak bu araştırma; akran değerlendirmenin öğretmen adaylarının mesleki bilgi ve becerileri üzerinde etkili olduğunu, eksik ve hatalı taraflarını görmelerine ve eleştirel düşünmelerine yarar sağladığını göstermiştir. Öğretmen adayları büyük oranda akran değerlendirmeye ilişkin olumlu görüşe sahip olsa da değerlendirmenin objektif olmadığı yönünde olumsuz görüşlere de ulaşılmıştır. Araştırmada değerlendirmecilerin grupların sunumlarına yapmış oldukları puanlamalar arasındaki uyumun istatistiksel olarak anlamlı ve orta düzeyde olduğu bulunmuştur. İleriki çalışmalarda öğrencilerin akranlarına yaptıkları değerlendirmelerle uzman değerlendirmeleri arasındaki orta düzeydeki uyumun nedenleri araştırılabilir. $\mathrm{Bu}$ kapsamda nedensel karşılaştırma araştırmaları yapılabilir. Akran değerlendirmenin öğretmen 
adaylarının mesleki bilgi ve becerileri üzerindeki etkisini ortaya koyan deneysel çalışmalar yapılabilir.

\section{Kaynaklar}

Adachi, C., Tai, J., ve Dawson, P. (2018a). A framework for designing, implementing, communicating and researching peer assessment. Higher Education Research \& Development, 37(3), 453-467.

Adachi, C., Tai, J. H.-M., ve Dawson, P. (2018b). Academics' perceptions of the benefits and challenges of self and peer assessment in higher education. Assessment \& Evaluation in Higher Education, 43(2), 294-306.

Akıllı, M (2007). Öz değerlendirme ve akran değerlendirmesi yöntemlerinin öğretmen eğitimine etkisi (Yüksek lisans tezi). Atatürk Üniversitesi, Erzurum.

Akpınar, M., ve Kranda, S. (2016). Sosyal bilgiler öğretmen adaylarının akran değerlendirmesine ilişkin görüşleri. Dicle Üniversitesi Ziya Gökalp Eğitim Fakültesi Dergisi, 29, 356-374.

ArchMiller, A., Fieberg, J., Walker, J.D., ve Holm, N. (2017). Group peer assessment for summative evaluation in a graduate-level statistics course for ecologists. Assessment \& Evaluation in Higher Education, 42(8), 1208-1220.

Baker, D. F. (2008). Peer assessment in small groups: A comparison of methods. Journal of Management Education, 32(2), 183-209.

Ballantyne, R., Hughes, K., ve Mylonas, A. (2002). Developing procedures for implementing peer assessment in large classes using an action research process. Assessment \& Evaluation in Higher Education, 27(5), 427-441.

Baruah, B., Ward, T., ve Jackson, N. (2018). Should Higher Education encourage the use of Intergroup Peer Assessment among students?. 17th International Conference on Information Technology Based Higher Education and Training (ITHET) (26-28 Nisan 2018), Olhao (Portugal), Retrieved from http://eprints.whiterose.ac.uk/132824/1/Baruah_Ward_Jackson_ITHET_2018.pdf

Bektaş, M., Horzum, M. B., ve Ayvaz, A. (2010). "Öğretmenlik uygulaması dersi öğretmen adayı akran değerlendirme ölçeği” geliştirme çalışması. E-Journal of New World Sciences Academy Education Sciences, 5(3), 1272-1280.

Bell, B., ve Cowie, B. (2001). The characteristics of formative assessment in science education. Science Education, 85(5), 536-553.

Biri, H. (2014). Akran değerlendirme yönteminin öğretmen eğitimine katkısı. (Yayımlanmamış yüksek lisans tezi). Karadeniz Teknik Üniversitesi, Tabzon.

Cassidy, S. (2006). Developing employability skills: peer assessment in higher education. Education+ Training, 48(7), 508-517.

Cheng, W., ve Warren, M. (2005). Peer assessment of language proficiency. Language Testing, 22(1), 93-121.

Cohen, M. D., ve Nath, J. L. (2006). Paired placements for early field experiences. Teacher Education and Practice, 19(1), 24-40.

Creswell, J. W., ve Clark, V. L. P. (2014). Karma Yöntem Araştırmaları Tasarımı ve Yürütülmesi (Y. Dede ve S. B. Demir, Çev. Ed.). Ankara: Anı Yayıncılık.

Çoban, İ., ve Polatcan, F. (2018). An analysis on views of prospective Turkish language teachers on peer assessment. European Journal of Education Studies, 4(4), 161-175.

Çolak, S. C. (2017). Yedinci sınıf denklemler konusunda akran değerlendirme uygulamasının öğrencilerin matematik başarısına etkisi. (Yayımlanmamış yüksek lisans tezi). Akdeniz Üniversitesi, Antalya. 
Demir, M. (2018). Using online peer assessment in an instructional technology and material design course through social media. Higher Education, 75(3), 399-414.

Dochy, F., Segers, M., ve Sluijsmans, D. (1999). The use of self-, peer and co-assessment in higher education: A review. Studies in Higher education, 24(3), 331-350.

Dündar, M. S. (2016). Akran değerlendirmesinin uzaktan eğitimde kullanımı ve akademik başarıya etkileri. (Yayımlanmamış yüksek lisans tezi). Ondokuz Mayıs Üniversitesi, Samsun.

Evans, C. (2013). Making sense of assessment feedback in higher education. Review of Educational Research, 83(1), 70-120.

Falchikov, N., ve Goldfinch, J. (2000). Student peer assessment in higher education: A meta-analysis comparing peer and teacher marks. Review of Educational Research, 70(3), 287-322.

Güneş, P., ve Kılıç, D. (2016). Dereceli puanlama anahtarı ile öz, akran ve öğretmen değerlendirmesi. Mehmet Akif Ersoy Üniversitesi Eğitim Fakültesi Dergisi, 1(39), 58-69.

Güzel, Z. (2018). Fen bilimleri öğretiminde öz ve akran değerlendirme uygulamalarının yer aldığı probleme dayalı öğrenme yaklaşımının öğrencilerin başarı ve tutumlarına etkisi. (Yayımlanmamış yüksek lisans tezi). Necmettin Erbakan Üniversitesi, Konya.

Hamzadayı, E., ve Dölek, O. (2017). Konuşma Becerisinin Değerlendirilmesinde Türkçe Öğretmenlerinin Yaklaşımları. Dil Eğitimi ve Araştırmaları Dergisi, 3(3), 135-151.

Hanrahan, S. J., ve Isaacs, G. (2001). Assessing self - and peer-assessment: The students' views. Higher Education Research \& Development, 20(1), 53-70.

Heritage, M. (2007). Formative assessment: What do teachers need to know and do?. Phi Delta Kappan, $89(2), 140-145$.

Izgar, G., ve Akturk, A. O. (2018). A mixed method research on peer assessment. International Journal of Evaluation and Research in Education, 7(2), 118-126.

Johnson, R. (2004). Peer assessments in physical education. Journal of Physical Education, Recreation \& Dance, 75(8), 33-40.

Karasar, N. (2012). Bilimsel Araştırma Yöntemleri (24. bs.). Ankara: Nobel Yayın Dağıtım.

Kwan, K-P., ve Leung, R. W. (1996). Tutor versus peer group assessment of student performance in a simulation training exercise. Assessment \& Evaluation in Higher Education, 21(3), 205-214.

Leenknecht, M. J., ve Prins, F. J. (2018). Formative peer assessment in primary school: the effects of involving pupils in setting assessment criteria on their appraisal and feedback style. European Journal of Psychology of Education, 33(1), 101-116.

Li, L. (2017). The role of anonymity in peer assessment. Assessment \& Evaluation in Higher Education, 42(4), 645-656.

Mika, S. (2006). Peer - and instructor assessment of oral presentations in Japanese university EFL classrooms: A pilot study. Waseda Global Forum, 3, 99-107. [Çevrim-içi: https://core.ac.uk/ download/pdf/144454460.pdf]

Murray, D., McGill, T., Thompson, N., ve Toohey, D. (2017). Can learners become teachers? Evaluating the merits of student generated content and peer assessment. Issues in Informing Science \& Information Technology, 14, 21-34.

Noonan, B., ve Duncan, C. R. (2005). Peer and self-assessment in high schools. Practical Assessment, Research and Evaluation, 10(17), 1-8.

Orsmond, P., Merry, S., ve Reiling, K. (1996). The importance of marking criteria in the use of peer assessment. Assessment \& Evaluation in Higher Education, 21(3), 239-250. 
Özdemir, O., ve Erdem, D. (2017). Sunum becerilerinin akran değerlendirmesine ve arkadaşlık ilişkisine etkisi. Turkish Journal of Educational Studies, 4(1). 21-43.

Panadero, E., ve Brown, G. T. L. (2017). Teachers' reasons for using peer assessment: positive experience predicts use. European Journal of Psychology of Education, 32(1), 133-156.

Patri, M. (2002). The influence of peer feedback on self-and peer-assessment of oral skills. Language Testing, 19(2), 109-131.

Planas-Lladó, A., Feliu, L., Castro, F., Fraguell, R. M., Arbat, G., Pujol, J., Suñol, J. J., ve Daunis-i-Estadella, P. (2018). Using peer assessment to evaluate teamwork from a multidisciplinary perspective. Assessment \& Evaluation in Higher Education, 43(1), 14-30.

Rotsaert, T., Panadero, E., Schellens, T., ve Raes, A. (2018). "Now you know what you're doing right and wrong!" Peer feedback quality in synchronous peer assessment in secondary education. European Journal of Psychology of Education, 33(2), 255-275.

Searby, M., ve Ewers, T. (1997). An Evaluation of the Use of Peer Assessment in Higher Education: a case study in the School of Music, Kingston University. Assessment \& Evaluation in Higher Education, 22(4), 371-383.

Sluijsmans, D., ve Prins, F. (2006). A conceptual framework for integrating peer assessment in teacher education. Studies in Educational Evaluation, 32(1), 6-22.

Song, Y., Guo, Y., ve Gehringer, E. F. (2017). An exploratory study of reliability of ranking vs. rating in peer assessment. International Scholarly and Scientific Research \& Innovation, 11(10), 2405-2409.

Sridharan, B., Muttakin, M. B., ve Mihret, D. G. (2018). Students' perceptions of peer assessment effectiveness: an explorative study. Accounting Education, 27(3), 259-285.

Steensels, C., Leemans, L., Buelens, H., Laga, E., Lecoutere, A., Laekeman, G., ve Simoens, S. (2006). Peer assessment: A valuable tool to differentiate between student contributions to group work?. Pharmacy Education, 6(2), 111-118.

Şahin, M. G., ve Kalyon, D. Ş. (2018). Öğretmen adaylarının öz-akran-öğretmen değerlendirmesine ilişkin görüşlerinin incelenmesi. Kastamonu Eğitim Dergisi, 26(4), 1055-1068.

Şen, A. İ. (2010). Akran öğretimi ve mikro öğretimin fizik öğretmen adaylarının öğretme becerilerine etkileri. Ĕ̆itim ve Bilim, 35(155), 78-88.

Topping, K. J. (1998). Peer assessment between students in colleges and universities. Review of Educational Research, 68(3), 249-276.

Topping, K. J. (2003). Self and peer assessment in school and university: Reliability, validity and utility. M. S. R. Segers, F. J. R. C. Dochy ve E. C. Cascallar (Ed.) içinde, Optimizing new modes of assessment: In search of qualities and standards (ss. 55-87). Dordrecht, Netherlands: Kluwer Academic Publishers.

Topping, K. J. (2009). Peer assessment. Theory Into Practice, 48(1), 20-27.

Tsivitanidou, O. E., Constantinou, C. P., Labudde, P., Rönnebeck, S., ve Ropohl, M. (2018). Reciprocal peer assessment as a learning tool for secondary school students in modeling-based learning. European Journal of Psychology of Education, 33(1), 51-73.

Tünkler, V., ve Güven, C. (2019). Mikroöğretim uygulamasının öğretmen adaylarının tamamlayıcı ölçmedeğerlendirme tekniklerine yönelik okuryazarlık düzeylerine etkisi. Hacettepe Üniversitesi Eğitim Fakültesi Dergisi, 34(2), 541-564.

Uyar, Ş., Demir, K., ve Aksekioğlu, B. (2016). Performans görevinin değerlendirilmesine ilişkin bir üçleme: Öz, akran ve öğretim üyesi değerlendirmesi. Uluslararası Türk Eğitim Bilimleri Dergisi, 4(7), 69-80.

Uysal, K. (2008). Öğrencilerin ölçme değerlendirme sürecine katılması: Akran değerlendirme ve öz değerlendirme. (Yayımlanmamış yüksek lisans tezi). Abant İzzet Baysal Üniversitesi, Bolu. 
Yıldırım, A., ve Şimşek, H. (2016). Sosyal bilimlerde nitel araştırma yöntemleri (10. bs.). Ankara: Seçkin Yayıncilik.

Yuan, J., ve Kim, C. (2018). The effects of autonomy support on student engagement in peer assessment. Educational Technology Research and Development, 66(1), 25-52.

Yurtseven, N., ve Altun, S. (2018). Öğretmenlerin program odaklı profesyonel gelişiminde öz-değerlendirme ve akran değerlendirmenin rolü. Hacettepe Üniversitesi Ĕ̆itim Fakültesi Dergisi, 33(1), 207-228.

Walker, A. (2001). British psychology students' perceptions of group-work and peer assessment. Psychology Learning and Teaching, 1(1), 28-36.

Wanner, T., ve Palmer, E. (2018). Formative self-and peer assessment for improved student learning: the crucial factors of design, teacher participation and feedback. Assessment \& Evaluation in Higher Education, 43(7), 1032-1047.

Wen, M. L., ve Tsai, C.-C. (2006). University students' perceptions of and attitudes toward (online) peer assessment. Higher Education, 51, 27-44. 